\title{
On-site Cytology for Development of Patient-Derived Three-dimensional Organoid Cultures - A Pilot Study
}

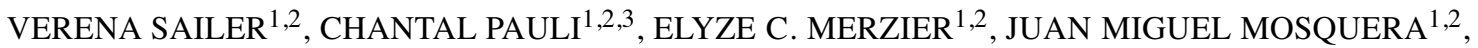 \\ HIMISHA BELTRAN ${ }^{2,4,5}$, MARK A. RUBIN ${ }^{1,2,4}$ and REMA A. RAO ${ }^{1,2}$ \\ ${ }^{1}$ Weill Cornell Medicine and New York Presbyterian, \\ Department of Pathology and Laboratory Medicine, New York, NY, U.S.A.; \\ ${ }^{2}$ Weill Cornell Medicine and New York Presbyterian, \\ Caryl and Israel Englander Institute for Precision Medicine, New York, NY, U.S.A.; \\ ${ }^{3}$ Institute of Surgical Pathology, University Hospital Zürich, Zurich, Switzerland; \\ ${ }^{4}$ Weill Cornell Medicine and New York Presbyterian, \\ Sandra and Edward Meyer Cancer Center, New York, NY, U.S.A.; \\ ${ }^{5}$ Weill Cornell Medicine and New York Presbyterian, Division of Medical Oncology, New York, NY, U.S.A.
}

\begin{abstract}
Background/Aim: Development of patient-derived three-dimensional $(3 D)$ organoid cultures is an emerging technique in the field of precision oncology. We aimed to integrate on-site adequacy evaluation using cytology into the tumor organoid development workflow to ensure precise characterization and growth of these cultures. Patients and Methods: Cancer patients were consented to a Precision Medicine trial. Fresh tissue was procured for genomic analyses as well as organoid development. Fresh tissue destined for organoid development was evaluated by preparing on-site cytology smears to ensure that only lesional tissue would be submitted for further cell culture work. Results: Cytology preparations were made from 64 different tumor samples and evaluated prior to tissue submission for organoid development. In $53(82.2 \%)$ of those tumor samples, the cytology preparation was diagnostic, thus providing adequate material for organoid development. Conclusion: Characterizing the tissue prior to submission for organoid development ensures submission of lesional tissue only. Furthermore, it is a cost-effective method that can help document patient diagnosis. This can be of
\end{abstract}

This article is freely accessible online.

Correspondence to: Rema A. Rao, MD, Department of Pathology and Laboratory Medicine, Caryl and Israel Englander Institute for Precision Medicine, Weill Cornell Medicine and New York Presbyterian, 525 East 68th Street, New York, NY, 10065, U.S.A. Tel: +1 2127462829 , Fax: +1 2127468359, e-mail: rer9052@med.cornell.edu

Key Words:Precision medicine, cytology, organoids, drug screening, DNA sequencing. importance in biopsies, since the tissue submitted for organoid development cannot be retrieved for clinical diagnosis afterwards. Our findings in this pilot study led to the implementation of on-site cytological evaluation in the tumor organoid development workflow at the Englander Institute for Precision Medicine, NY, USA.

Personalized medicine, also referred to as Precision Medicine (PM), is the approach to treat a patient's disease by taking into account the molecular landscape of the individual tumor or disease process. In addition to its role in oncology, PM is also employed in the treatment of other chronic conditions such as autoimmune disorders. In the United States, the Precision Medicine Initiative ${ }^{\circledR}$ was launched by President Barack Obama in early 2015 in order to facilitate individualized patient care. Recently, the National Institute of Health (NIH) awarded \$55 million to enroll one million patients in a multi-institutional precision medicine trial (1).

In the field of Precision Oncology, the development of patient-derived 3D tumor organoid cultures is an emerging model that can be a valuable tool for predictive in vitro drug testing (2). Although cell lines have long been established for preclinical drug testing, they do not sufficiently recapitulate the innate tumor heterogeneity and therefore the genomic complexity. Organoid cultures are thus the preferable method for predictive drug testing (3). Organoids are derived from stem cells and are self-organizing and selfrenewing (4). Since organoids maintain the genetic representation of a patient's tumor, they are a readily available source of high-quality DNA and RNA for next generation sequencing (NGS). In order to initiate organoid development, fresh tumor tissue is collected and processed 


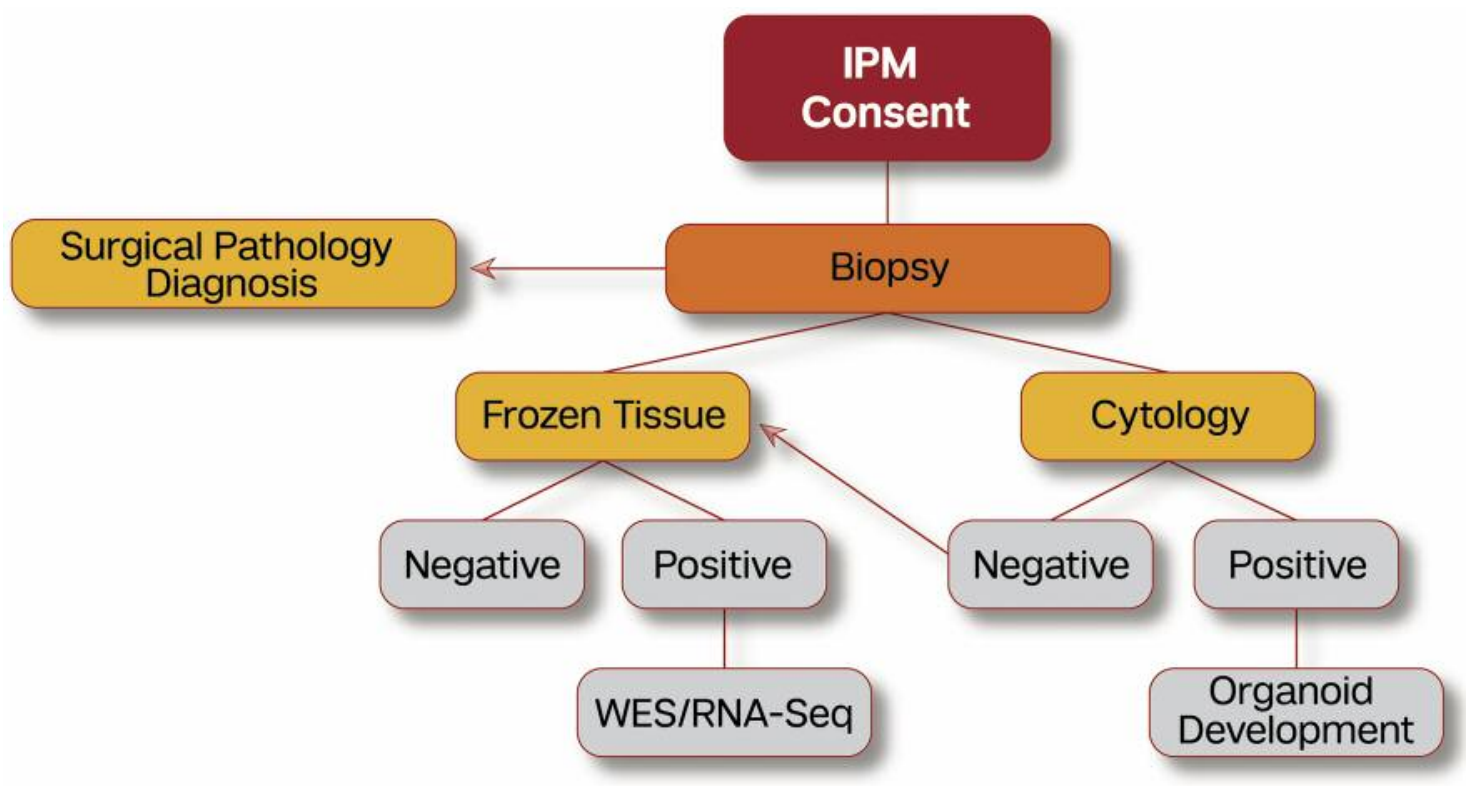

Figure 1. Fresh tissue collection workflow at the Institute for Precision Medicine (IPM), NY, USA. Consented patients undergo a repeat, usually CT-guided biopsy or a surgical resection. Tissue is triaged and prioritized for surgical pathology to establish a diagnosis. Part of the remaining tissue is snap-frozen to preserve DNA and RNA for whole-exome sequencing (WES) and RNASeq. The remainder of the tissue will be submitted for organoid development if on-site cytologic assessment is positive. However, if on-site cytology is negative, the tissue is not discarded but instead added to the fresh tissue destined for WES. These samples are snap-frozen and frozen sections are reviewed. If the tumor cell content is sufficient, DNA and RNA will be extracted and send for sequencing.

in a time sensitive manner. Weeber et al. successfully cultured organoids in 10 of 14 cases $(71 \%)$ of metastatic colorectal carcinoma (5). Successful generation of organoid cultures was higher (up to $90 \%$ ) in samples from primary tumors when compared with metastases (6).

Organoid development is a time- and cost-intense process. As yet, no cost estimate per organoid development has been published. Organoids are usually propagated in Matrigel Matrix (Corning Inc. USA), which closely resembles extracellular matrix. It provides a scaffold for cells to grow and proliferate (7). Matrigel is a relatively expensive medium priced at approximately $\$ 318$ per bottle. Costs for technical staff adds to the expenditure for cell culture infrastructure and consumables. Submitting tissue for organoid development "blindly", i.e. without prior characterization, can result in spending money and time propagating benign organoids. Submitting only lesional tissue for further processing is therefore paramount. Rapid on-site evaluation (ROSE) is a common practice in cytopathology that assesses tissue samples for adequacy of material for diagnostic purposes. We have recently shown, that cytological evaluation of organoids within a few weeks into their development can successfully characterize them (8). In the present study, we aimed to integrate on-site cytological evaluation during tissue collection to identify viable tumor for organoid development and guide decision-making on the early fate of these organoids.

\section{Materials and Methods}

Between October 2015 and July 2016 tumor tissue from patients diagnosed with a variety of malignant and benign tumors was collected as described previously (9). The Institutional Review Board at Weill Cornell Medical College approved the protocol for tissue collection for the overarching Precision Medicine clinical trial (IRB\#1305013903). Written informed consent was obtained from all enrolled patients. Tissue was triaged according to pre-defined operational procedures with clinical diagnosis and WES/RNA sequencing being the most important considerations (Figure 1). From the remainder of the tissue, a very small amount (less than $0.5 \mathrm{~mm}$ ) of a grossly suspicious area was used to prepare a cytology smear as described before (8). The air-dried smear was then stained with Diff-Quik staining solution (Siemens Medical Solutions USA, INC, Malvren, PA, USA) and reviewed by a board-certified cytopathologist (RR). A positive diagnosis resulted in submission of the tissue for further organoid development. A negative interpretation resulted in non-submission of tissue for organoid growth. The tissue was instead added to the tissue destined for WES. These tissue samples were snap-frozen and frozen sections were reviewed for their overall tumor cell content before proceeding to DNA-extraction for WES. IBM SPSS Statistics, Version 24.0 (IBM Corporation, Armonk, NY, USA) software was used for statistical analysis. 

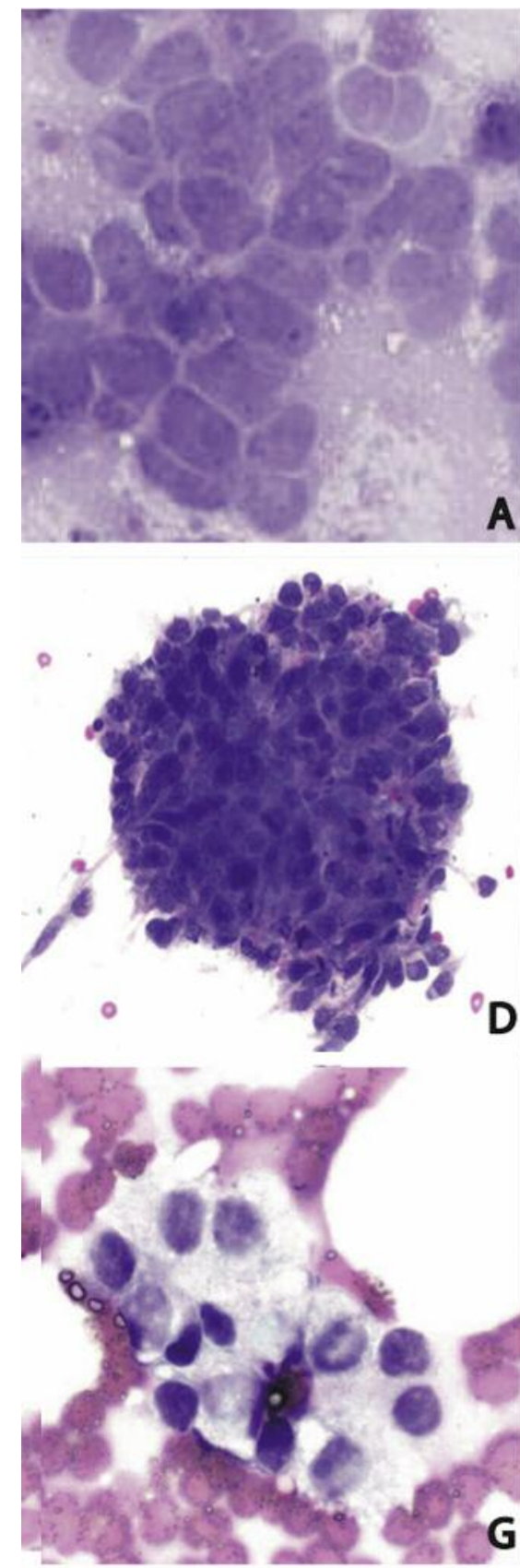
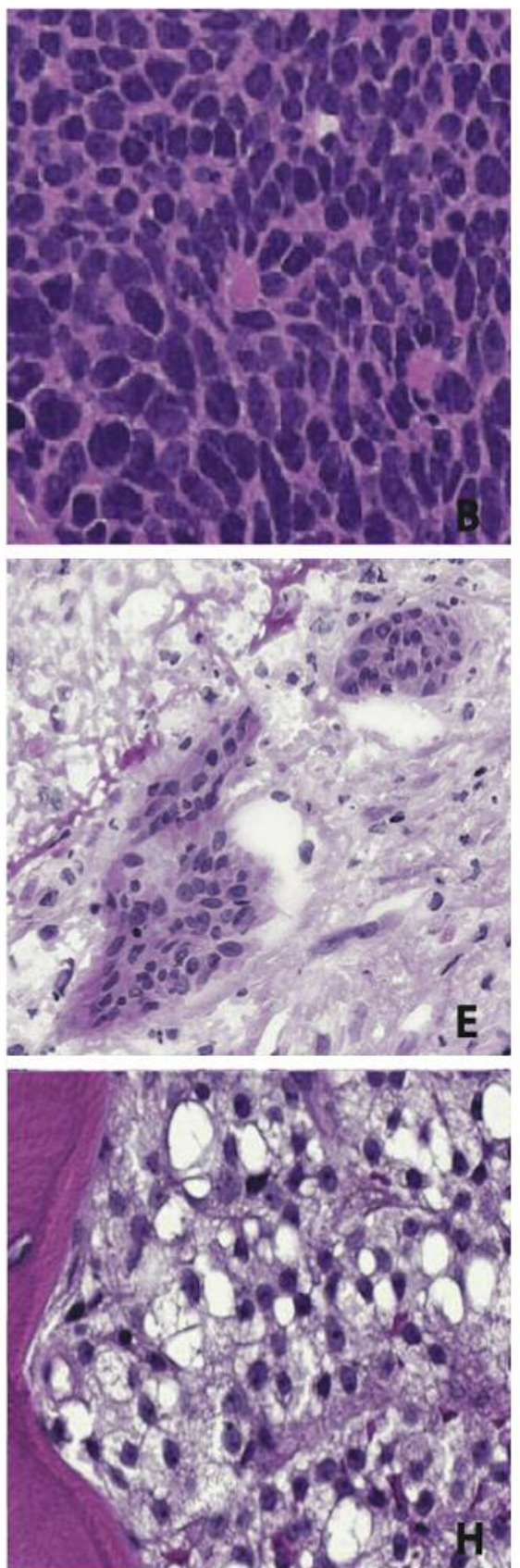
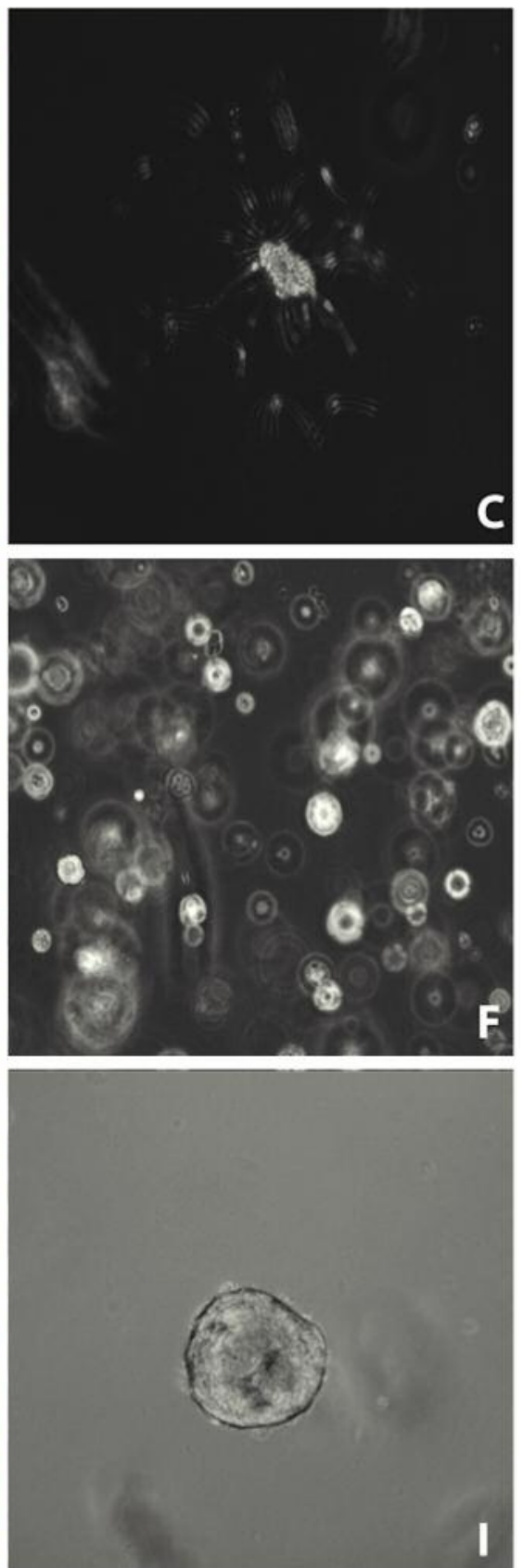

Figure 2. Examples of positive cytology, concurrent histology and subsequent organoids: Small-cell prostate cancer, right humerus metastasis. Airdried $D Q$ stained smear, $40 \times(A)$, histology $(H \& E), 20 \times(B), 3 D$ organoid in cell culture, $5 \times(C)$. High-grade invasive urothelial carcinoma of the bladder (post-neoadjuvant treatment), bladder resection. Air-dried DQ stained smear, 20x (D), histology (H\&E), 20x (E), 3D organoid in cell culture, $5 \times(F)$. Metastatic prostatic adenocarcinoma, left iliac bone biopsy. Air-dried DQ stained smear, $40 \times(G)$, histology $(H \& E), 20 \times(H), 3 D$ organoid in cell culture, $5 \times(I)$.

\section{Results}

Sixty-four fresh tumor tissue samples were collected. Patient tissue samples were procured from $2(3.1 \%)$ benign and 62 (96.9\%) malignant tumors. Thirty-seven (57.8\%) samples were taken from core biopsies, and $27(42.2 \%)$ from resection specimens. Histology of primary tumors included $36(56.3 \%)$ adenocarcinomas from a variety of primary sites (13 prostate, 23 gastrointestinal). In addition, 8 (12.5\%) urothelial carcinomas, 5 (7.8\%) renal cell carcinomas, 6 
(9.4\%) mesenchymal tumors, $2(3.1 \%)$ primary brain tumors, $2(3.1 \%)$ small cell carcinomas of prostatic origin and 2 $(3.1 \%)$ squamous cell carcinomas (1 esophageal primary, 1 anal primary) and one papillary thyroid carcinoma (1.6\%) were collected. Benign tumor types included one ovarian fibroma and one schwannoma $(3.1 \%)$, which were collected due to the clinical suspicion of malignancy in these cases.

A total of $53(82.2 \%)$ cytology smears contained tumor cells sufficient for diagnosis (Figure 2). This sensitivity is comparable with data reported in the literature on ROSE (10). Eleven $(17.2 \%)$ cytology smears were negative, of which four were from bone biopsies, three from lymph node biopsies, two from liver biopsies, one from a peritoneal biopsy and one from a pleura biopsy. All cytology smears from resection specimens were diagnostic. The cytologic evaluation of one such negative bone biopsy was initially interpreted as indeterminate due to the presence of few "atypical" cells, and the concurrent core biopsy was reported as negative for malignant cells. The tissue in this case was initially suspended in cell culture media for less than 24 hours, but was finally processed as a formalinfixed paraffin embedded (FFPE) block following the final core biopsy pathology.

Of the 53 tumor samples that were processed for organoid development, $36(67.9 \%)$ contained viable tumor cells that formed globular structures in cell culture. Failure of organoid growth in the remaining $17(32.1 \%)$ cases was mostly related to small biopsy sample size and tumor samples of prostatic origin.

\section{Discussion}

We have previously shown that cytology smears are a useful diagnostic tool in the field of organoid research (8). In the present study, we demonstrate that determining the adequacy of tissue using cytology smears prior to submission for organoid development is feasible and effective. It ensures that only lesional tissue and not tissue contaminants are grown, thereby improving process efficiency in terms of time and cost. Preparation of a cytology smear is a relatively simple and less expensive technique especially if one is trained in good smear preparation techniques. In a small series of ten tumor organoids from patients with pancreatic cancer (11), two organoid cultures failed to grow. The authors in this series attributed this failure to necrosis following neoadjuvant therapy in one case. In the other case, benign stromal overgrowth led to the failure of the cultures (11). We hypothesize, that in both above cases, pre-organoid cytology could have revealed the absence of viable tumor cells before submitting the tissue for cell culture work.

In general, when tumor tissue is submitted for organoid development, it cannot be retrieved and reprocessed for diagnostic evaluation. In addition, the sample that is provided for organoid development can be limited in size with minimal tumor volume. Cytologic assessment of the tumor tissue prior to submission for organoid development can be of added value in determining the quality of the sample.

We and others have shown, that the molecular make-up of the primary tumor genomic as well as transcriptomic alterations are preserved throughout organoid propagation (Dr. Chantal Pauli, personal communication) (12). The ability to capture tumor heterogeneity makes organoids superior to traditional cancer cell lines $(13,14)$. Therefore, organoids can be an excellent tool in the future for ex vivo drug screening to select targeted therapy $(15,16)$. Testing therapeutic agents in preclinical 3D cell cultures may also help reduce unnecessary side-effects and might reduce treatment costs. If several organoids from the same patients are maintained in culture, treatment induced selection processes and potential resistant mechanisms can be studied (17). In addition, organoids can be propagated from a variety of highly prevalent primary tumors like colorectal and pancreas cancer, thus addressing the needs of a large number of patients (18). However, organoid development has not been implemented in clinical practice yet (19). Further studies analyzing cost-benefit ratio, turnaround time and survival are necessary.

In summary, our pilot study demonstrates the efficacy of on-site cytology in the context of precision oncology and organoid development. These results have led to the implementation of on-site cytology in our workflow at the Englander Institute for Precision Medicine.

\section{Conflicts of Interest}

The Authors made no conflict of interest disclosures.

\section{Funding Support}

No specific funding was obtained for this study.

\section{References}

1 Collins FS and Varmus H: A new initiative on precision medicine. N Engl J Med 372: 793-795, 2015.

2 Fatehullah A, Tan SH and Barker N: Organoids as an in vitro model of human development and disease. Nat Cell Biol 18: 246-254, 2016.

3 Francies HE, Barthorpe A, McLaren-Douglas A, Barendt WJ and Garnett MJ: Drug sensitivity assays of human cancer organoid cultures. Methods Mol Biol, 2016.

4 Clevers H: Modeling development and disease with organoids. Cell 165: 1586-1597, 2016.

5 Weeber F, van de Wetering M, Hoogstraat M, Dijkstra KK, Krijgsman O, Kuilman T, Gadellaa-van Hooijdonk CG, van der Velden DL, Peeper DS, Cuppen EP, Vries RG, Clevers H and Voest EE: Preserved genetic diversity in organoids cultured from biopsies of human colorectal cancer metastases. Proc Natl Acad Sci U A 112: 13308-13311, 2015. 
6 van de Wetering M, Francies HE, Francis JM, Bounova G, Iorio F, Pronk A, van Houdt W, van Gorp J, Taylor-Weiner A, Kester L, McLaren-Douglas A, Blokker J, Jaksani S, Bartfeld S, Volckman R, van Sluis P, Li VS, Seepo S, Sekhar Pedamallu C, Cibulskis K, Carter SL, McKenna A, Lawrence MS, Lichtenstein L, Stewart C, Koster J, Versteeg R, van Oudenaarden A, SaezRodriguez J, Vries RG, Getz G, Wessels L, Stratton MR, McDermott U, Meyerson M, Garnett MJ and Clevers H: Prospective derivation of a living organoid biobank of colorectal cancer patients. Cell 161: 933-945, 2015.

7 Mousseau Y, Mollard S, Qiu H, Richard L, Cazal R, Nizou A, Vedrenne N, Remi S, Baaj Y, Fourcade L, Funalot B and Sturtz FG: In vitro 3D angiogenesis assay in egg white matrix: comparison to Matrigel, compatibility to various species, and suitability for drug testing. Lab Invest 94: 340-349, 2014.

8 Pauli C, Puca L, Mosquera JM, Robinson BD, Beltran H, Rubin MA and Rao RA: An emerging role for cytopathology in precision oncology. Cancer Cytopathol 124: 167-173, 2016.

9 Beltran H, Eng K, Mosquera JM, Sigaras A, Romanel A, Rennert H, Kossai M, Pauli C, Faltas B, Fontugne J, Park K, Banfelder J, Prandi D, Madhukar N, Zhang T, Padilla J, Greco N, McNary TJ, Herrscher E, Wilkes D, MacDonald TY, Xue H, Vacic V, Emde AK, Oschwald D, Tan AY, Chen Z, Collins C, Gleave ME, Wang Y, Chakravarty D, Schiffman M, Kim R, Campagne F, Robinson BD, Nanus DM, Tagawa ST, Xiang JZ, Smogorzewska A, Demichelis F, Rickman DS, Sboner A, Elemento $\mathrm{O}$ and Rubin MA: Whole-Exome Sequencing of Metastatic Cancer and Biomarkers of Treatment Response. JAMA Oncol 1: 466-474, 2015.

10 Nayak A, Sugrue C, Koenig S, Wasserman PG, Hoda S and Morgenstern NJ: Endobronchial ultrasound-guided transbronchial needle aspirate (EBUS-TBNA): a proposal for on-site adequacy criteria. Diagn Cytopathol 40: 128-137, 2012.

11 Boj SF, Hwang CI, Baker LA, Chio I, Engle DD, Corbo V, Jager M, Ponz-Sarvise M, Tiriac H, Spector MS, Gracanin A, Oni T, Yu KH, van Boxtel R, Huch M, Rivera KD, Wilson JP, Feigin ME, Ohlund D, Handly-Santana A, Ardito-Abraham CM, Ludwig M, Elyada E, Alagesan B, Biffi G, Yordanov GN, Delcuze B, Creighton B, Wright K, Park Y, Morsink FH, Molenaar IQ, Borel Rinkes IH, Cuppen E, Hao Y, Jin Y, Nijman IJ, Iacobuzio-Donahue C, Leach SD, Pappin DJ, Hammell M, Klimstra DS, Basturk O, Hruban RH, Offerhaus GJ, Vries RG, Clevers $\mathrm{H}$ and Tuveson DA: Organoid models of human and mouse ductal pancreatic cancer. Cell 160: 324-338, 2015.
12 Schutte M, Risch T, Abdavi-Azar N, Boehnke K, Schumacher D, Keil M, Yildiriman R, Jandrasits C, Borodina T, Amstislavskiy V, Worth CL, Schweiger C, Liebs S, Lange M, Warnatz H-J, Butcher LM, Barrett JE, Sultan M, Wierling C, Golob-Schwarzl N, Lax S, Uranitsch S, Becker M, Welte Y, Regan JL, Silvestrov M, Kehler I, Fusi A, Kessler T, Herwig R, Landegren U, Wienke D, Nilsson M, Velasco JA, Garin-Chesa P, Reinhard C, Beck S, Schafer R, Regenbrecht CRA, Henderson D, Lange B, Haybaeck J, Keilholz U, Hoffmann J, Lehrach H and Yaspo M-L: Molecular dissection of colorectal cancer in pre-clinical models identifies biomarkers predicting sensitivity to EGFR inhibitors. Nat Commun 8: 14262, 2017.

13 Francies HE and Garnett MJ: What role could organoids play in the personalization of cancer treatment? Pharmacogenomics 16 : 1523-1526, 2015.

14 Golovko D, Kedrin D, Yilmaz OH and Roper J: Colorectal cancer models for novel drug discovery. Expert Opin Drug Discov 10: 1217-1229, 2015.

15 Eglen RM and Randle DH: Drug Discovery Goes ThreeDimensional: Goodbye to Flat High-Throughput Screening? Assay Drug Dev Technol 13: 262-265, 2015.

16 Vela I and Chen Y: Prostate cancer organoids: a potential new tool for testing drug sensitivity. Expert Rev Anticancer Ther 15: 261-263, 2015 .

17 Sachs $\mathrm{N}$ and Clevers H: Organoid cultures for the analysis of cancer phenotypes. Curr Opin Genet Dev 24: 68-73, 2014.

18 Gao D and Chen Y: Organoid development in cancer genome discovery. Curr Opin Genet Dev 30: 42-48, 2015.

19 Halfter K and Mayer B: Bringing 3D tumor models to the clinic - predictive value for personalized medicine. Biotechnol J 12, 2017. doi: 10.1002/biot.201600295
Received February 22, 2017

Revised March 11, 2017

Accepted March 14, 2017 